\title{
KEBUTUHAN SOSIAL EKONOMI KELUARGA DALAM MENANGANI GIZI BURUK ANAK BALITA (Studi di Desa Tampunabale Kecamatan Pasikolaga)
}

Noviana, Muhammad Rusli, dan Megawati A. Tawulo Jurusan Ilmu Kesejahtraan Sosial, Fakultas Ilmu Sosial Dan Ilmu Politik Universitas Halu Oleo, Kendari

Jl. H. E. A. Mokodopit, Kendari 93232

e-mail: novianabasrikesos@gmail.com

\begin{abstract}
ABSTRAK
Penelitian ini bertujuan untuk mengetahui kebutuhan soaial ekonomi keluarga pada pada masyarakat di desa Tampunabale Kecamatan Pasikolaga dan untuk mengetahui apakah mengetahui upaya keluarga dalam mengatasi status gizi buruk anak balita di desa Tampunabale Kecamatan Pasikolaga. Jenis penelitian ini adalah penelitian deskripstif kualitatif. Teknik pengumpulan data dilakukan dengan cara observasi, wawancara dan dokumentasi dengan informan penelitian sebanyak 10 orang anak di Desa Tampunabale Kecamatan Pasikolaga.

Hasil penelitian menunjukan bahwa kebutuhan sosial ekonomi masyarakat Tampunabale Kecamatan Pasikolaga secara umum cukup baik hal ini ditunjukan melalui indikator kesehatan yang terglong cukup baik dan juga indikator perumahan yang semua masyarakat telah memilki rumah namun demikian pada indikator tingkat pendidikan masyarakat masih cukup rendah sedangkan kondisi ekonomi yang ditunjukan melalui pekerjaan maka mayoritas masyarakat desa Tampunabale Kecamatan Pasikolaga bekerja sebagai petani dengan tingkat pendapatan sedang dan tingkat pengeluaran tergolong rendah. Upaya Keluarga dalam Mengatasi Gizi Buruk Anak Balita di Desa Tampunabale Kecamatan Pasikolaga dilakukan melalui posyandu secara rutin yang dilakukan oleh orang tua yang memiliki anak balita, konsultasi ke tenaga kesehatan terdekat dan memanfaatkan dukungan sosial keluarga untuk mengatasi masalah gizi buruk pada anak usia balita di desa Tampunabale Kecamatan Pasikolaga.
\end{abstract}

Kata Kunci: Kebutuhan Sosial, Ekonomi, Keluarga, Gizi Buruk Anak.

\section{PENDAHULUAN}

Pembangunan masyarakat Indonesia merupakan usaha yang dilakukan pemerintah untuk menyejahterakan kehidupan bangsa. Pembangunan suatu bangsa dapat berhasil dilaksanakan dengan adanya sumber daya manusia (SDM) yang berkualitas. Ada banyak faktor yang dapat mempengaruhi tersedianya sumber daya manusia yang berkualitas, antara lain kesehatan (fisik dan mental), faktor gizi, dan perkembangan kemampuan terhadap ilmu dan teknologi. Indeks Pembangunan Manusia (Human Development Index) merupakan indikator yang 
dapat digunakan untuk mengetahui tinggi rendahnya kualitas sumber daya manusia. Salah satu faktor utama yang menentukan Indeks Pembangunan Manusia adalah pendidikan, kesehatan, dan ekonomi yang berhubungan dengan status gizi suatu masyarakat (Azwar, 2004).

Salah satu faktor penting yang menentukan tingkat kesehatan dan kesejahteraan manusia adalah tingkat terpenuhinya gizi yang diperoleh. Gizi seseorang dikatakan baik apabila terdapat keseimbangan dan keserasian antara perkembangan fisik dan perkemban gan mental orang tersebut. Terdapat hubungan antara status gizi dengan konsumsi makanan. Tingkat status gizi optimal akan tercapai apabila kebutuhan gizi optimal terpenuhi (Wiryo, 2002).

Gizi sangat diperlukan oleh setiap orang utamanya adalah anak dan balita. Status gizi anak atau balita merupakan salah satu indikator utama pembangunan dan sebagai prasyarat untuk kemajuan sosial ekonomi masyarakat dalam jangka panjang (Marianto, dkk 2005). Kekurangan gizi berkontribusi terhadap tingginya tingkat kecacatan, penyakit dan kematian. Kurang gizi juga mempengaruhi pertumbuhan fisik jangka panjang dan perkembangan anak-anak, dan dapat menyebabkan tingginya penyakit kronis dan cacat dalam kehidupan sosial masyarakat dewasa.

Di sisi lain tingginya tingkat kurang gizi membahayakan pertumbuhan ekonomi di masa depan dengan mengurangi potensi intelektual dan fisik dari seluruh penduduk (Irianto, K dan Kusno Waluy 2007). Masalah gizi pada hakekatnya adalah masalah kesehatan masyarakat, namun penanggulangannya tidak dapat dilakukan dengan pendekatan medis dan pelayanan kesehatan saja. Masalah gizi dapat timbul karena berbagai faktor, oleh karena itu penanggulangan masalah gizi ini harus melalui pendekatan yang melibatkan berbagai sektor yang terkait termasuk sektor keluarga.

Status ekonomi rumah tangga memiliki peranan yang sangat bersar terhadap pemenuhan kebutuhan ekonomi keluarga termasuk keadaan kesehatan yang berhubungan dengan keterpenuhan gizi suatu rumah tangga, hal ini berkaitan dengan kemampuan rumah tangga dalam menyediakan pangan dan kemampuan akses pelayanan kesehatan bagi anggota rumah tangga. Rumah tangga dengan 
pendapatan yang rendah akan mengalami kesulitan dalam penyedian pangan dan ini berdampak pada keadaan gizi anggota rumah tangga terutama anak balita.

Ketahanan pangan keluarga adalah gambaran ekonomi keluarga tentang kemampuan keluarga untuk memenuhi kebutuhan pangan anggota rumah tangga dari segi jumlah, mutu, dan ragamnya sesuai dengan budaya setempat. Sedangkan ketahanan pangan rumah keluarga tercemin dari ketersediaan, kemampuan daya beli, dan keterjangkauan keluarga dalam memenuhi kebutuhan pangan. Bila keluarga mengalami kesulitan dalam memenuhi kebutuhan pangan yang disebabkan oleh ketidakmampuan dalam menyediakan makanan karena jarak tempuh untuk mendapatkan makanan tidak terjangkau atau tidak mampu membeli karena segi ekonomi, maka keluarga tersebut dikatakan tidak memenuhi kondisi ekonomi yang baik. Kondisi yang tidak baik ini dapat berakibat pada status gizi yang buruk terhadap anggota keluarga.

Di sisi lain jumlah anggota rumah tangga yang besar juga tidak bisa dikesampingkan dalam upaya untuk memenuhi kebutuhannya layanan kesehatan dan pangan tiap anggaran ruma tanggah akan terhamba dan pada akhirnya akan berpengaruh pada keadaan gizi. Zat gizi yang diperlukan oleh anak-anak dan anggota keluarga yang masih muda pada umumnya lebih tinggi dari kebutuhan orang dewasa karena mereka sedang mengalami pertumbuhan yang sangat pesat (Sediaoetama, 2008).

Berdasarkan hasil observasi yang dilakukan peneliti di Desa Tampunabale menggambarkan tingkat status gizi buruk anak balita yang lahir pada bulan Januari hingga Juni 2019 sebanyak 10 anak, hal ini di sebabkan oleh kondisi ekonomi keluarga belum sanggup memenuhi kebutuhan asupan gizi yang cukup atau kurangnya fungsi dan peran keluarga dalam mengatasi gizi buruk terhadap anak balita. Menurut data Posiandu anak Desa Tampunabale menggambarkan ada beberapa anak balita yang tergolong dalam status gizi buruk (Sumber sekunder data Posyandu anak). Kondisi ini menimbulkan asumsi tentang adanya hubungan antara kondisi sosial dan fungsi keluarga dalam menangani anak yang berstatus gizi buruk. Berdasarakan data awal tersebut maka menarik untuk dilakukan penelitian lanjutan untuk mengkaji secara empirik dan ilmiah tentang fungsi 
keluarga dalam menangani gizi buruk melalui penelitian dengan judul Kebutuhan Sosial Ekonomi Keluarga dalam Menangani Gizi Buruk Anak Balita (Studi di Desa Tampunabale Kecamatan Pasikolaga).

\section{METODE PENELITIAN}

Jenis penelitian yang dilakukan oleh penulis adalah penelitian kualitatif. Jenis penelian ini untuk memberikan gambaran atau menjelaskan secara detail tentang data mengenai kondisi sosial ekonomi dan status gizi dilakukan dengan pengukuran Indeks Lingkar Lengan Atas Menurut Umur (LLA/U), sedangkan untuk mengambil data untuk tingkat sosial ekonomi yaitu menggunakan pedoman wawancara.

Informan penelitian dalam penelitian ini adalah semua orang tua balita yang memilika anak gizi buruk yang berada di Desa Tampunabale Kecamatan Pasikolaga yang berjumlah 10 orang. Adapun pemilihan informan dilakukan dengan penunjukan langsung kepada subyek yang dianggap memiliki pengetahuan tentang permasalahan yang akan diteliti yaitu kebutuhan sosial ekonomi keluarga dalam menangani masalah gizi buruk pada anak balita.

\section{PEMBAHASAN}

\section{Kebutuhan Sosial Ekonomi Keluarga Pada Masyarakat di desa Tampunabale Kecamatan Pasikolaga}

Gambaran kebutuhan sosial ekonomi dalam keluarga pada suatu masyarakat umumnya dapat dideskripsikan melalui terpenuhinya kebutuhan dasar yang dapat menunjang kelangsungan suatu keluarga yang mencakup variabel kebutuhan dasar yang meliputi sandang, pangan dan tempat tinggal serta kebutuhan penunjang berupa kebutuhan kesehatan, pendidikan, hiburan dan kebutuhan pengembangan berupa investasi masa depan. Adapun lebih jelasnya tentang deskripsi kebutuhan sosial ekonomi keluarga masyarakat Desa Tampunabale Kecamatan Pasikolaga dalam mengatasi masalah gizi buruk pada anak dapat dijabarkan berdasarkan variabel-variabel dan indikator-indikator sebagai berikut: 


\section{a. Pemenuhan Kebutuhan Dasar Keluarga (Basic Needs) Pada Masyarakat Desa Tampunabale Kecamatan Pasikolaga}

\section{1) Kebutuhan Pangan Keluarga Pada Masyarakat Desa Tampunabale} Kecamatan Pasikolaga

Kebutuhan pangan adalah merupakan kebutuhan pokok yang berhubungan langsung pada masalah keterpenuhan gizi pada anggota keluarga dalam suatu masyarakat. Adapun kondisi pemenuhan kebutuhan makan atau pandang pada keluarga dalam masyarakat Desa Tampunabale Kecamatan Pasikolaga terungkap melalui wawancara dengan bapak La Ahmad tentang pemenuhan kebutuhan dasar mengungkapkan bahwa:

"Kebutuhan dasar ini tentu saja berhubungan dengan pangan, pakaian dan juga tempat tinggal, jadi secara umum masyarakat Desa Tampunabale Kecamatan Pasikolaga pada dasarnya mampu memenuhi kebutuhan dasar tersebut, namun demikian dalam hubunganya dengan penanganan gizi buruk anak memang tidak semua keluarga mampu memberikan makanan kepada anak yang memenuhi kriteria kecukupan gizi anak yang disebabkan keterbatasan ekonomi dan factor lainya seperti keterjangkauan setiap keluarga dalam mengakses layanan kesehatan. Maka oleh karena itu angka gizi buruk di Desa Tampunabale Kecamatan Pasikolaga masih tergolong cukup tinggi. (wawancara dengan bapak La Ahmad 21 Desember 2019).

Berdasarkan hasil beberapa wawancara di atas menunjukan bahwa secara umum pemenuhan kebutuhan dasar terhadap pangan pada keluarga di masyarakat desa Tampunabale secara umum terpenuhi, akan tetapi dalam hubunganya dengan masalah pemenuhan gizi pada anak tidak semua keluarga memiliki kemampuan untuk memenuhi kebutuhan pangan yang memenuhi angka kecukupan gizi sehingga dengan kondisi ini memberikan pengaruh langsung pada peningkatan angka gizi buruk di Desa Tampunabale Kecamatan Pasiokolaga.

\section{2) Kebutuhan Tempat Tinggal}

Rumah atau tempat tinggal merupakan salah satu kebutuhan pokok bagi kehidupan manusia dimana merupakan kebutuhan dasar yang harus di penuhi oleh mahluk hidup yang bermasyarakatr, karena fungsi rumah bagi masyarakat tidak hanya sekedar pemenuhan kebutuhan tempat tinggal atau tempat berlindung saja akan tetapi diselaraskan dengan kebutuhan lain seperti keamanan dan kenyamanan dalam lingkungan keluarga maupun masyarakat sekitarnya. 
Kedudukan rumah yang sangat penting dalam kehidupan sosial individu dalam masyarakat sehingga faktor rumah menjadi salah satu indikator dalam menentukan kehidupan sosial ekonomi dalam masyarakat. Pada masyarakat dengan tingkat sosial ekonomi mapan biasanya memiliki rumah yang elit dan mewah sebaliknya pada kelompok masyarakat yang memiliki status sosial kalangan menengah kebawah hanya memiliki rumah dalam kategori sedang atau sederhana. Adapun lebih jelasnya tentang variable rumah sebagai salah satu variabel yang dapat menggambarkan kebutuhan ekonomi keluarga pada masyarakat di desa Tampunabale Kecamatan Pasikolaga terungkap melalui wawancara dengan bapak Harun dalam keterangnya mengungkapkan bahwa

"Rumah atau tempat tinggal memang menjadi kebutuhan yang sangat mendasar bagi setiap keluarga dalam anggota masyarakat. Kondisi yang sama juga pada masyarakat desa Tampunabale Kecamatan Pasikolaga rumah adalah menjadi kebutuhan utama maka oleh karena itu setiap anggota keluarga dalam desa Tampunabale Kecamatan Pasikolaga telah memiliki rumah dengan luas dan bentuk bangunan rumah yang bermacam-macam baik rumah yang bersifat permanen, non permanen maupun semi permanen. (Wawancara dengan bapak Harun 1 Januari 2020)

Berdasarkan beberapa hasil wawancara di atas menunjukan bahwa setiap keluaraga yang berada di desa Tampunabale Kecamatan Pasikolaga memiliki rumah dengan kriteria yang variatif yaitu non permanen, semi permanen maupun bersifat permanen. Kondisi kepemilikan rumah pada setiap anggota keluarga didorong dengan kedudukan rumah sebagai kebutuhan pokok yang paling utama sehingga setiap keluarga dalam masyarakat desa Tampunabale Kecamatan Pasikolaga memiliki rumah sebagai tempat tinggal.

\section{3) Kebutuhan Sandang/Pakaian}

Kebutuhan sandang adalah kebutuhan yang berhubungan dengan busana atau pakaian yang kita gunakan, setiap manusia membutuhkan pakaian untuk menutup tubuh mereka dan untuk kenyamanan. Tetapi saat ini pakaian bukan hanya untuk menutup tubuh atau aurat tetapi juga sebagai identitas dari diri seseorang atau kelompok masyarakat. Kebutuhan sandang adalah bagian dari kebutuhan primer yang harus terpenuhi, meskipun memang tanpa sandang seseorang masih bisa bertahan hidup. Tetapi jika seseorang tidak mengenakan 
pakaian, maka umumnya dia akan merasa kedinginan, masuk angin, dan merasa malu untuk bergaul dengan orang lain. Adapun lebih jelasnya tentang pemenuhan kebutuhan sandang pada masyarakat desa Tampunabale Kecamatan Pasikolaga terungkap melalui wawancara dengan bapak Harun dalam keterangnya mengungkapkan bahwa:

"Kebutuhan pakaian juga adalah merupakan kebutuhan dasar yang mutlah harus dimiliki oleh setiap keluarga sehingga karena merupakan kebutuhan mutlak maka setiap keluarga mengupayakannya. Maka dalam hal pemenuhan kebutuhan sandang di desa Tampunabale Kecamatan Pasikolaga saya pikir masih dapat terpenuhi oleh setiap anggota keluarga baik diperoleh melalui usaha sendiri pada setiap keluarga maupun melalui bantuan dari pihak sanak keluarga lainya. (Wawancara dengan bapak Harun 1 Januari 2020).

Berdasarkan beberapa hasil wawancara di atas menunjukan bahwa kebutuhan keluarga dalam memenuhi kebutuhan sandang di desa desa Tampunabale Kecamatan Pasikolaga maka secara umum dapat memenuhi kebutuhan tersebut, meskipun kebutuhan sandang tidak memiliki pengaruh langsung pada upaya penanganan gizi buruk pada anak akan tetapi tetap merupakan kebutuhan pokok yang juga diutamakan dalam pemenuhanya.

\section{4) Kebutuhan Kesehatan}

Kesehatan adalah merupakan kebutuhan yang sangat mendasar oleh setiap orang, oleh karena itu setiap orang dalam kelompok masyarakat akan selalu berusaha untuk mendapatkan layanan kesehatan dengan berbagai alternative sarana memperoleh kesehatan itu sendiri. Kondisi kesehatan meliputi kondisi fisik, mental dan lingkungan. Suatu masyarakat jelas terikat dengan keberadaan pola hidup yang di tampilkan oleh masyarakat yang bersangkutan dalam suatu lingkungan.

Adapun lebih jelasnya tentang tingkat kesehatan masyarakat desa desa Tampunabale Kecamatan Pasikolaga terungkap melalui wawancara dengan bapak Helmi salah satu responden penelitian mengungapkan bahwa:

"Tingkat kesehatan pada masyarakat desa Tampunabale Kecamatan Pasikolaga secara umum saya melihatnya masih cukup baik hal ini dilihat dari jumlah masyarakat yang sakit sementara maupun yang sakit sudah cukup lama atau sakit menahun dari segi jumlahnya hanya 1 sampai 3 
orang saja maka oleh karena itu tingkat kesehatan cukup baik. (Wawancara dengan bapak Helmi 2 Januari 2020)

Berdasarkan hasil wawancara di atas menunjukan bahwa secara umum tingkat kesehatan masyarakat di desa Tampunabale Kecamatan Pasikolaga tergolong baik dengan tingkat kesehatan masyarakat yang secara umum membaik dengan ditunjukan dengan data masyarakat yang terserang penyakit di desa Tampunabale Kecamatan Pasikolaga sangat sedikit. Kondisi ini didukung oleh tersedianya sarana dan prasarana kesehatan dan tenaga kesehatan yang dapat dengan mudah dijangkau masyarakat desa Tampunabale Kecamatan Pasikolaga sehingga mendukung tingkat kesehatan masyarakat

\section{b. Pemenuhan Kebutuhan Penunjang}

Sebuah keluarga selain dituntut untuk memenuhi kebutuhan dasar yang bersifat mutlak maka terdapat kebutuhan lain yang juga tidak dapat dipisahkan dari kebutuhan dasar yaitu kebutuhan psikoogi yang berhubungan dengan pemberian kasih sayang antara anggota keluarga, pendidikan dan perlindungan termasuk masalah kesehatan anggota keluarga. Adapun lebih jelasnya tentang pemenuhan kebutuhan psikologi dalam keluarga dalam hubunganya dengan penanganan gizi buruk anak dapat dideskripsikan melalui indicator pemberian pendidikan pada anggota keluarga dan juga pemenuhan kebutuhan kesehatan anggota keluarga. Adapun lebih jelasnya tentang indicator tersebut dapat dijabarkan sebagai berikut:

\section{1) Pemenuhan Kebutuhan Pendidikan Anggota Keluarga Pada Masyarakat di desa Tampunabale Kecamatan Pasikolaga}

Tingkat pendidikan adalah jenjang pendidikan formal yang telah di selesaikan oleh setiap orang dalam kelompok masyarakat sampai mendapatkan keterangan lulus. Tingkat pendidikan turut mempengaruhicara berpikir dan bertindak seseorang dalam lingkungan masyarakat. Pendidikan juga cukup mempengaruhi pola hidup seseorang dalam masyarakat termasuk dalam hal memilih dan mendapatkan pekerjaan yang layak sehingga mengakibatkan seseorang berkembang lebih baik dan dinamis dalam kehidupan masyarakat termasuk status sosial ekonominya. 
Pendidikan memang sangat penting dalam mempengaruhi kehidupan dan status sosial seseorang dalam masyarakat, sehingga pendidikan menjadi salah satu sarana sebagian orang dalam upaya meningkatkan status kehidupan sosial dan ekonominya. Adapun lebih jelasnya tentang tingkat pendidikan masyarakat desa Tampunabale Kecamatan Pasikolaga terungkap melalui wawancara dengan bapak La Ahmad tentang tingkat pendidikan masyarakat mengungkapkan bahwa

"tingkat pendidikan masyarakat secara umum di desa Tampunabale Kecamatan Pasikolaga masih tergolong rendah hingga sedang. Kondisi ini dapat dilihat dengan tingkat pendidikan masyarakat pada umumnya atau sebagaian besar hanya menamatkan pendidikan pada tingkat sekolah dasar SD maupun SMP sehingga hanya sebagian kecil yang melanjukan atau menyelesaikan pendidikan sampai SMA hingga perguruan tinggi. (wawancara dengan bapak La Ahmad 21 Desember 2019)

Berdasarkan hasil beberapa wawancara di atas menggambarkan bahwa kondisi social masyarakat desa Tampunabale pada aspek pendidikan masih tergolong rendah kondisi ini ditunjukan dengan tingkat pendidikan masyarakat desa Tampunabale yang pada umumnya adalah hanya menempuh pendidikan sampai pada pendidikan SD hingga SMP dan hanya sebagian kecil masyarakatnya yang menempuh pendidikan sampai pada pendidikan SMA hingga perguruan tinggi. Dengan demikian data hasil wawancara di atas menggambarkan bahwa tingkat pendidikan masyarakat desa Tampunabale masuk kategori rendah.

\section{2) Pemenuhan Kebutuhan Pekerjaan masyarakat desa Tampunabale Kecamatan Pasikolaga \\ Pekerjaan akan menentukan kondisi social dan ekonomi suatu keluarga} oleh karena itu pekerjaan dan pendapatan yang diperleh dari bekerja diperlukan untuk memenuhi segala kebutuhan yang diperlukan oleh setiap anggota keluarga. Pekerjaan tidak hanya mempunyai nilai ekonomi namun usaha manusia untuk mendapatkan kepuasan dan mendapatkan imbalan atau upah, berupa barang dan jasa akan terpenuhi kebutuhan hidupnya. Pekerjaan seseorang akan mempengaruhi kemampuan ekonominya, untuk itu bekerja merupakan suatu keharusan bagi setiap individu sebab dalam bekerja mengandung dua segi, kepuasan jasmani dan terpenuhinya kebutuhan hidup. 
Pekerjaan itu sendiri dapat diklasifikasi ke dalam status pekerjaan utama atau juga pekerjaan sampingan. Dalam hubungan dengan status pekerjaan tersebut maka untuk mengetahui status pekerjaan masyarakat di Tampunabale Kecamatan Pasikolaga dapat diketahui berdasarkan hasil wawancara dengan bapak La Ahmad dalam tanggapanya tentang pekerjaan mengungkapkan bahwa:

"Pekerjaan saya sendiri bekerja sebagai petani kebun dan merupakan pekerjaan utama selain sebagai petani juga maka untuk meningkatkan pendapatan juga terkadang alih profesi sebagai pekerja atau buruh tani pada perkebunan yang akan diolah oleh masyarakat lainya di desa Tampunabale Kecamatan Pasikolaga (wawancara dengan bapak La Ahmad 21 Desember 2019)

Berdasarkan hasil wawancara dari beberapa responden di atas menunjukan bahwa pekerjaan pada masyarakat desa Tampunabale cukup beragam dengan status pekeerjaan yang variatif pula. Adapun jenis pekerjaan yang ditekuni oleh masyarakat desa Tampunabale antara lain adalah sebagai petani,buruh tani,tukang,ibu rumah tangga,penjual dan juga pegawai serta hanya sebagai ibu rumah tangga.

\section{3) Pendapatan pada masyarakat desa Tampunabale Kecamatan Pasikolaga}

Tingkat pendapatan masyarakat tergantung pada pekerjaan masyarakat yang ditekuni. Dalam dunia bisnis pendapatan adalah jumlah uang yang di terima dari aktivitas yang dikerjakan, kebanyakan dari penjualan produk dana jasa kepada pelanggan. Sedangkan bagi masyarakat petani maka pendapatan adalah penerimaan yang di peroleh dari hasil usaha yang telah dikerjakan berupa hasil pertanian yang dilakukan masyarakat.Bagi pedagang maka pendapatan diperoleh dari hasil daganganya. Kondisi yang sama juga dengan tingkat pendapatan masyarakat desa Tampunabale didapatkan dari hasil usaha yang ditekuni masyarakat baik sebagai petani, pedagang, buruh,PNS dan pekerjaan lainya. Adapun lebih jelasnya tentang tingkat pendapatan masyarakat terungkap melalui wawancara dengan bapak bapak La Ahmad dalam keteranganya tentang tingkat pendapatan masyarakat mengungkapkan bahwa

"Tingkat pendapatan pada setiap anggota keluarga dalam anggota masyarakat tentu saja berbeda-beda sebagai contoh saya sebagai masyarakat petani dalam sebulan memiliki tingkat pendpaatan yang 
relative rendah hingga sedang apabila dibandingkan dengan tingkat pendapatan masyarakat yang pegawai atau wiraswasta. Secara estimasi pendapatan sebagai petani di desa Tampunabale Kecamatan Pasikolaga minimal berkisar Rp1.000.000 sampai Rp 1.500.000 perbulanya, namun tentu saja pendapatan tersebut tidak tetap akan tetapi tergantung pada musim panen bagi para petani sedangkan para pedangang atau Pegawai maka tentu saja memiliki tingkat pendapatan yang berbeda-beda pula. (wawancara dengan bapak La Ahmad 21 Desember 2019)

Berdasarkan keterangan dari beberapa hasil wawancara di atas menunjukan bahwa tingkat pendapatan masyarakat desa Tampunabale Kecamatan Pasikolaga pada umumnya adalah sangat bergantung pada hasil pertanian karena umumnya masyarakatnya adalah petani. Kondisi ini juga menunjukan bahwa tingkat pendapatan sangat bergantung pada jenis pekerjaan yang ditekuni dalam memenuhi kebutuhan hidup sehingga secara estimasi tingkat pendapatan masyarakat desa Tampunabale Kecamatan Pasikolaga dalam setiap bulanya adalah berkisar antara Rp 1.000.000 sampai Rp 2000.000 rupiah perbulanya.

\section{a. Upaya Keluarga dalam Mengatasi Status Gizi Buruk Anak Balita di Desa Tampunabale Kecamatan Pasikolaga}

Peranan keluarga begitu kompleks dalam hubunganya dengan keadaaan anak dalam kelurga. Dalam keluarga dibagi menjadi empat fungsi yaitu fungsi edukatif, ekonomi, afeksi, dan fungsi religious. Adapun lebih jelasnya tentang pelaksanaan fungsi keluarga dalam hubungnya dengan upaya mengatasi gizi buruk anak balita di desa Tampunabale dapat dijabarkan melalui varibael-variabel berikut:

\section{a. Mengikuti Kegiatan Posyandu secara Rutin}

Posyandu menjadi instrumen penting penanggulangan gizi buruk. Kedudukan Posyandu menjadi pusat pelayanan kesehatan yang paling dekat dengan masyarakat. Di Posyandu, para ibu bisa mendapatkan layanan imunisasi bagi anak serta mengontrol tumbuh kembang putra-putrinya. "Jika Ibu-ibu rutin membawa anak ke Posyandu maka perkembangan anak bisa dipantau secara terus menerus. Apabila terindikasi kekurangan gizi bisa segera diatasi. Pentingnya motivasi orangtua untuk sadar kegiatan Posyandu di masyarakat sehingga bisa mencegah gizi buruk pada anak mereka. Dalam hubunganya dengan pelaksanaan posyandu sebagai salaha satu upaya orang tua atau keluarga dalam mengatasi gizi 
buruk anak balita di desa Tampunabale terungkap melalui wawancara dengan bapak La Ahmad, dalam keteranganya bahwa

"Posyandu memang menjadi keharusan bagi ibu-ibu yang memiliki anak usia balita untuk dapat melakukan pemeriksaan secara intensif tentang kesehatan anak anak balita. Sehingga selaku orang tua maka tentu saja secara pribadi sangat mendukung setiap orang tua untuk meningikuti kegiatan posyandu secara rutin kepada para orang tua yang memiliki anak usia balita. Melalui kegiatan psoyandu ini diharapkan dapat menjadi salah satu solusi alternative dalam mengatasi masalah gizi buruk anak balita karena dapat mendapatkan penyuluhan maupun sosialisasi dari tenaga kesehatan yang dilakukan melalui posyandu. (wawancara dengan bapak La Ahmad 21 Desember 2019)

Berdasarkan hasil wawancara dari beberapa responden di atas menunjukan bahwa posyandu rutin yang dilakukan oleh ibu balita menjadi salah satu alternative yang dapat dilakukan orang tua anak balita di desa Tampunabale Kecamatan Pasikolaga. Melalui kegiatan psoyandu maka orang tua dapat mengetahui tentang konsumsi kecukupan gizi anak balita sehingga dapat memaksimalkan asupan gizi pada anak balita pada masa pertumbuhnya. Disisi lain melalui psoyandu orang tua anak dapat memperoleh sosialisasi dalam upaya pencegahan gizi buruk pada anak usia balita.

\section{b. Konsultasi Gizi Balita Ke Tenaga Kesehatan Terdekat}

Konsultasi tentang gizi balita ke tenaga kesahatan adalah merupakan langkah lain yang dapat dilakukan oleh orang tua anak balita untuk mencegah terjadinya gizi buruk. Tenaga kesehatan seperti bidan di lingkungan desa adalah cara untuk mengatasi terjadinya gizi buruk pada anak usia balita. Kondisi yang sama juga dilakukan di desa Tampunabale Kecamatan Pasikolaga sebagai salah satu upaya dalam mengatasi gizi buruk pada anak usia balita maka orang tua melakukan konsultasi kepada tenaga kesehatan yaitu bidan di desa Tampunabale Kecamatan Pasikolaga. Pernyataan di atas terungkap melalui wawancara dengan ibu Salmawati dalam keteranganya tentang konsultasi ke tenaga kesehatan sebagai salah satu upaya mencegah terjadinya gizi buruk anak di desa Tampunabale Kecamatan Pasikolaga mengungkapkan bahwa

"Konsultasi kepada tenaga kesehatan juga memang salah satu cara tepat yang dapat dilakukan orang tua untuk mencegah atau mengantisipasi 
terjadinya gizi buruk anak usia balita. Saya sendiri melakukan konsultasi setiap 1 bulan sekali untuk memastikan tingkat pertumbuhan anak saya. Namun demikian tentu saja tidak semua orang tua melakukan hal ini dengan berbagai factor mulai dari factor ekonomi atau factor lainya seperti tingkat kesadaran orang tua tentang pentingnya kecukupan gizi pada anak usia balita. (Wawancara dengan ibu Salmawati 2 Januari 2020)

Berdasaran hasil wawancara diatas menunjukan bahwa konsultasik ke tenaga kesehatan terdekat sebagai salah satu upaya untuk mencegah terjadinya gizi buruk pada anak adalah merupakan langkah tepat yang dapat dilakukan orang tua anak untuk memastikan kecukupan asupan gizi pada anak agar terhindar dari gizi buruk. Namun demikian konsultasi kepada tenaga kesehatan tentu saja tidak dapat dilakukan oleh semua orang dengan pertimbangan masalah ekonomi dan juga factor kesadaran orang tua tentang pentingnya pengetahuan tentang kecukupan asupan gizi pada anak untuk mencegah terjadinya gizi buruk pada anak usia balita.

\section{c. Memanfaatkan Dukungan Sosial Keluarga}

Kehidupan masyarakat desa identik dengan suasana kekeluargaaan atau sifat komunal yang melekat untuk saling membantu antara satu dengan yang lainya. Kelahiran anak pada suatu keluarga selain sebagai kebahagian bagi keluarga inti yang terdiri dari ayak, istri dan anak juga menjadi kebahagian bagi keluarga lainya. Maka dalam menyambut anak balita yang baru lahir umumnya keluarga lainya memberikan bantuan atau uluran tangan untuk membantu anak dalam usia balita untuk dapat terpenuhi asupan gizi yang dibutuhkan anak dalam pertumbuhanya. Langkah dukungan social ini menjadi salah satu bagian dari upaya keluarga dalam mengatasi atau mencegah gizi buruk pada anak. Pernyataan di atas terungkap melalui wawancara dengan ibu Wa Mila salah satu responden dalam penelitian ini dalam tanggapanya dengan dukungan social keluarga sebagai salah satu bagian dari upaya mencegah gizi buruk pada anak mengungkapkan bahwa

"Dukungan social keluarga memang menjadi salah satu bagian dari upaya yang dapat mengatasi masalah gizi buruk pada anak usia balita namun dukungan social keluarga tersubut sifatnya pasif hanya dapat menerima apabila ada bantuan dari pihak keluarga dalam pemenuhan kebutuhan gizi pada pertumbuhan anak sehingga meskipun dukungan social kelarga 
sangat efektif namun demikian tentu saja tidak dapat dikatakan sebagai salah satu upaya yang ideal dalam upaya mengatasi gizi buruk pada anak usia balita namun demikian dari aspek kontribusi memang sangat berpengaruh dalam mengatasi masalah gizi buruk pada anak usia balita. (Wawancara dengan ibu Ibu Wa Mila 26 Desember 2019)

Berdasarkan beberapa keterangan di atas maka dapat diketahui bahwa memanfaatkan dukungan social keluarga menjadi salah satu bagian dari upaya masyarakat desa Tampunabale dalam mengatasi upaya gizi buruk pada anak. Namun demikian langkah memanfaatkan dukungan social kelurga bukan merupakan solusi satu-satunya dalam mencegah terjadinya gizi buruk pada anakakan tetapi secara simultan tentang melakukan posyandu secara rutin dan juga konsultasi ke tenaga kesehatan terdekat dilakukan secara bersama sehingga sedapat mungkin dapat mencegah terjadinya gizi buruk di desa Tampunabale Kecamatan Pasikolaga.

\section{PENUTUP}

Berdasarkan hasil penelitian dan pembahasan dalam penelitian ini maka penulis menyimpulkan bahwa

1. Kebutuhan sosial ekonomi keluarga pada masyarakat Tampunabale Kecamatan Pasikolaga secara umum yang mencakup kebutuhan dasar (basic needs), kebutuhan sandang, pangan tempat tinggal, kesehatan, pekerjaan dan pendapatan, serta pendidikan telah terpenuhi namun demikian pada pemenuhan kebutuhan dasar khususnya pangan atau makanan sebagian besar keluarga tidak memiliki kemampuan untuk memberikan makanan yang memenuhi angka asupan gizi yang cukup pada setiap anak dalam keluarga sehingga angka gizi buruk anak masih tergolong tinggi.

2. Upaya keluarga dalam Mengatasi Status Gizi Buruk Anak Balita di Desa Tampunabale Kecamatan Pasikolaga dilakukan melalui posyandu secara rutin yang dilakukan oleh orang tua yang memiliki anak balita, konsultasi ke tenaga kesehatan terdekat dan memanfaatkan dukungan sosial keluarga untuk mengatasi masalah status gizi buruk pada anak usia balita di Desa Tampunabale Kecamatan Pasikolaga 


\section{DAFTAR PUSTAKA}

Achmad Djaeni Sediaoetama. 2008. Ilmu Gizi Untuk Mahasiswa Dan Profesi. Jilid 1. Jakarta : Penerbit Dian Rakyat

Almatsier, S. 2001. Prinsip Dasar Ilmu Gizi. PT. Gramedia Pustaka Utama. Jakarta

Arfida, 2004. Ekonomi Sumber Daya Manusia. Penerbit: Ghalia Indonesia

Azwar, A. 2004. Kecenderungan Masalah Gizi dan Tantangan di Masa Datang; disampaikan pada pertemuan advokasi program perbaikan gizi menuju Keluarga Sadar Gizi, di Hotel Sahid Jaya,Jakarta

Basri Ikhwan Abidin. 2005. Islam dan Pembngunan Ekonomi, (Jakarta : Gema Insani Press

Dalyono. 2005. Psikologi Pendidikan. Jakarta: Rineka Cipta

Damayanti, Ika Putri, dkk. 2008. Buku Ajar Asuhan Kebidanan Komprehensip Pada Ibu Bersalin Dan Anak Baru Lahir. Yogyakarta: Deepublish

Deswarni Idrus dan Gatot Kunanto, 1990. Epidemiologi I. Jakarta: Pusdiknakes..

Dewa Nyoman S dan Bachyar Bakri, 2002, Penilaian Status Gizi, Jakarta: Buku Kedokteran EGC

Fadhilah. 2002. Faktor-Faktor Yang Mempengaruhi Status Gizi Balita Di

Pemukiman Lubuk Kecamatan Ingin Jaya Aceh Besar Tahun 2011. Fakultas

Kesehatan Masyarakat.

Irianto, K dan Kusno Waluyo.(2007). Gizi Dan Pola Hidup Sehat. Bandung: Yrama Widya

Khairuddin, H. 2002. Sosiologi Keluarga. Yogyakarta : Liberty

Masithah,T., Soekirman, Drajad martianto. (2005). Hubungan Pola Asuh Makan

Dan Kesehat an Dengan Status Gizi Anak Batita Di Desa Mulya Harja. http://repositori.ipb.ac.id/kumpulanfile/3432825_abs.pdf di unduh 2 juli 2019

Mazhahiri, Husain. 2001. Pintar Mendidik Anak (Panduan Lengkap Bagi Orang

Tua, Guru dan Masyarakat Berdasarkan Ajaran Isalam). Jakarta: Lentera.

Muchtadi, Deddy 2002. gizi untuk bayi : Asi, Susu Formula dan Makanan

Tambahan. Jakarta: Pustaka Sinar Harapan.

Mufidah, 2008. Psikologi Kekuarga Islam Berwawasan Gender, Malang: UIN Malang Press

Poerwadarminta. 1982. Kamus Besar Bahasa Indonesia. Jakarta: Balai Pustaka

Semiawan, C. 1998. Lingkungan Belajar Yang Mengundang Suatu Pendekatan

Bermakna dalam Meningkatkan Perkembangan Anak Retardasi Mental.

Disertasi. Jakarta: Institut Keguruan.

Singgih Purwanto,1996. Psikologi perkembangan anak dan remaja gunung. Mulia Jakarta.

Soekanto, Soerjono. (2006). Sosiologi Suatu Pengantar. Jakarta: PT. Raja 
Grafindo Persada.

Soekirman, 2000, Ilmu Gizi dan Aplikasinya, Jakarta: Direktorat Jendral

Pendidikan Tinggi.

Soekirman. 2012. Perlu paradigma baru untuk menanggulangi masalah gizi makro di Indonesia. Institut Pertanian Bogor (IPB). gizi. depkes. go.id/wpcontent /uploads/2012/05/prof-soekirman.pdf diakses pada tanggal 15 Juli 2019

Sudiharto, 2007, Asuhan Keperawatan Keluarga dengan Pendekatan Keperawatan Transkultural, Jakarta EGC.

Sugiyono. (2012). Metode Penelitian Kuantitatif Kualitatif dan R\&D. Bandung: Alfabeta.

Suharjo. 2003. Berbagai Cara Pendidikan Gizi. Bumi Aksara. Jakarta

Suharsimi Arikunto. (2002). Prosedur Penelitian Suatu Pendekatan Praktik. Jakarta: Rineka Cipta.

Suhendi,Wahyu, 2000.fungsi keluarga.Bandung:Alfa Beta

Supariasa dkk. (2001).Penilaian Status Gizi. Jakarta: Penerbit Buku Kedokteran EGC.

T. Gilarso. (1998). Ekonomi Indonesia Sebuah Pengantar. Yogyakarta: Kanisius.

Tolan,R.W.J.2013. Staphylococcus Aureus Infection Emedicine. Medscape. com/ article/ 971358. (02 Juli 2019)

Wirdhana dkk 2013. Buku Pegangan Kader Tentang Bimbingan dan Pembinaan Keluarga Remaja. Jakarta: BKKBN. 